\title{
Blocking GARP-mediated activation of TGF- $\beta 1$ did not alter innate or adaptive immune responses to bacterial infection or protein immunization in mice
}

\author{
Mélanie Gaignage ${ }^{1} \cdot$ Xuhao Zhang $^{1}$ - Julie Stockis ${ }^{1}$. Olivier Dedobbeleer ${ }^{1}$. Camille Michiels ${ }^{1}$. Perrine Cochez ${ }^{1}$. \\ Laure Dumoutier ${ }^{1} \cdot$ Pierre G. Coulie ${ }^{1,2} \cdot$ Sophie Lucas ${ }^{1,2} \mathbb{0}$
}

Received: 19 April 2021 / Accepted: 22 November 2021 / Published online: 1 January 2022

(c) The Author(s) 2021

\begin{abstract}
Transmembrane protein GARP binds latent TGF- $\beta 1$ to form GARP:(latent)TGF- $\beta 1$ complexes on the surface of several cell types including Tregs, B-cells, and platelets. Upon stimulation, these cells release active TGF- $\beta 1$. Blocking TGF- $\beta 1$ activation by Tregs with anti-GARP:TGF- $\beta 1 \mathrm{mAbs}$ overcomes resistance to PD1/PD-L1 blockade and induces immune-mediated regressions of murine tumors, indicating that Treg-derived TGF- $\beta 1$ inhibits anti-tumor immunity. TGF- $\beta 1$ exerts a vast array of effects on immune responses. For example, it favors differentiation of $\mathrm{T}_{\mathrm{H}} 17$ cells and B-cell switch to IgA production, two important processes for mucosal immunity. Here, we sought to determine whether treatment with anti-GARP:TGF- $\beta 1 \mathrm{mAbs}$ would perturb immune responses to intestinal bacterial infection. We observed no aggravation of intestinal disease, no systemic dissemination, and no alteration of innate or adaptative immune responses upon oral gavage of $C$. rodentium in highly susceptible $I l 22 r^{-/-}$mice treated with anti-GARP:TGF- $\beta 1 \mathrm{mAbs}$. To examine the effects of GARP:TGF- $\beta 1$ blockade on Ig production, we compared $\mathrm{B}$ cell- and $\mathrm{T}_{\mathrm{H}}$ cell- responses to OVA or CTB protein immunization in mice carrying deletions of Garp in Tregs, B cells, or platelets. No alteration of adaptive immune responses to protein immunization was observed in the absence of GARP on any of these cells. Altogether, we show that antibody-mediated blockade of GARP:TGF- $\beta 1$ or genetic deletion of Garp in Tregs, B cells or platelets, do not alter innate or adaptive immune responses to intestinal bacterial infection or protein immunization in mice. Anti-GARP:TGF- $\beta 1 \mathrm{mAbs}$, currently tested for cancer immunotherapy, may thus restore anti-tumor immunity without severely impairing other immune defenses.
\end{abstract}

\section{Précis}

Immunotherapy with GARP:TGF- $\beta 1$ mAbs may restore anti-tumor immunity without impairing immune or inflammatory responses required to maintain homeostasis or host defense against infection, notably at mucosal barriers.

Keywords GARP · TGF- $\beta 1 \cdot$ Monoclonal antibody $\cdot$ Intestinal bacterial infections $\cdot$ Citrobacter rodentium $\cdot$ Protein immunization

Mélanie Gaignage and Xuhao Zhang have contributed equally to this work.

Sophie Lucas

sophie.lucas@uclouvain.be

1 de Duve Institute, Université Catholique de Louvain, avenue Hippocrate 74, B1.74.04, 1200 Brussels, Belgium

2 Walloon Excellence in Life Sciences and Biotechnology (WELBIO), Wavre, Belgium

\section{Introduction}

Transforming growth factor- $\beta 1$ (TGF- $\beta 1$ ) is a potent immunosuppressive cytokine that plays an important role in the maintenance of immune tolerance [1,2]. Most cells, including immune cells, produce TGF- $\beta 1$ in a latent, inactive form, in which the mature TGF- $\beta 1$ dimer is non-covalently associated with the latency-associated peptide (LAP) [3, 4]. Only a few cell types are able to activate the cytokine, by releasing mature TGF- $\beta 1$ from LAP and allowing its binding to the TGF- $\beta$ receptor. Dendritic cells and epithelial cells can 
activate latent TGF- $\beta 1$ deposited in the extracellular matrix via binding of integrins $\alpha \mathrm{V} \beta 8$ or $\alpha \mathrm{V} \beta 6$, respectively, to RGD motifs in LAP [5, 6]. We and others showed that Tregs, B cells, and platelets activate latent TGF- $\beta 1$ presented on their surface by a transmembrane protein called GARP [7-9].

Activation of TGF- $\beta 1$ from GARP:(latent)TGF- $\beta 1$ complexes on Tregs requires integrin $\alpha \mathrm{V} \beta 8$ [10]. We recently developed monoclonal antibodies against GARP:TGF- $\beta 1$ complexes that block TGF- $\beta 1$ activation and immunosuppression by human and mouse Tregs [11, 12]. We showed that anti-GARP:TGF- $\beta 1 \mathrm{mAbs}$ overcome resistance to PD1/ PD-L1 blockade and induce immune-mediated regressions of tumors in mice. In addition to blocking Treg immunosuppression and restoring anti-tumor immunity, antiGARP:TGF- $\beta 1 \mathrm{mAbs}$ could exert unwanted side effects, owing on one hand to their ability to block TGF- $\beta 1$ activation from non-Treg GARP-expressing cells, and on the other hand to the pleiotropic functions exerted by TGF- $\beta 1$ in immunity, including adaptive immunity. Notably but non exclusively, TGF- $\beta 1$ is known to induce switch to IgA production in $\mathrm{B}$ cells, and differentiation of naïve $\mathrm{CD} 4^{+} \mathrm{T}$ cells into $\mathrm{T}_{\mathrm{H}} 17$ effectors in presence of IL-6 or into peripheral Tregs (pTregs) in presence of IL-2 [13-15]. $T_{H} 17$, pTregs and IgA-producing B cells are adaptive immune effectors playing important roles in the establishment and maintenance of balanced immune responses at epithelial barriers. The use of blocking anti-GARP:TGF- $\beta 1 \mathrm{mAbs}$ for the purpose of cancer immunotherapy could therefore perturb immunity against bacterial infections in the intestine.

Citrobacter rodentium is a natural murine bacterial pathogen causing intestinal infection, inflammation, and disease that closely resembles disease caused by enteropathogenic Escherichia coli and enterohemorrhagic E. coli in humans. Oral gavage of $C$. rodentium in WT mice causes infection and inflammation limited to colon and caecum, which are rapidly controlled by the immune system, preventing severe intestinal disease $[16,17]$. Production of IL-22 is required to protect the host against development of severe colitis [18]. In the early phase of infection, IL-22 is produced by innate immune cells such as group 3 innate lymphoid cells. The cytokine is crucial to limit bacterial expansion, notably by inducing production of RegIII $\beta$ and RegIII $\gamma$ antimicrobial peptides by epithelial cells $[19,20]$. In later phases, IL-22 is also produced by $\mathrm{CD}^{+} \mathrm{T}$ cells, including $\mathrm{T}_{\mathrm{H}} 17$ cells. In addition to $T_{H} 17$ cells, adaptive immune responses against C. rodentium, which are required to clear the infection [21, 22], also imply $\mathrm{T}_{\mathrm{H}} 1$ cells and $\mathrm{B}$ cells producing pathogenspecific IgGs.

Here, we examined whether anti-GARP:TGF- $\beta 1 \mathrm{mAbs}$ could perturb innate or adaptive immune responses at mucosal barriers, using oral gavage of $C$. rodentium in WT or highly susceptible $I l 22 r^{-/-}$mice as a model of intestinal bacterial infection. We also examined whether the absence of GARP:TGF- $\beta 1$ complexes would alter T cell- or B cellresponses against protein immunization in mice carrying Treg-, B cell- or platelet-specific deletions of the Garp gene.

\section{Methods}

\section{Mice}

All mice were bred at the SPF animal facility of the UCLouvain. Cell type-specific Garp KOs and WT littermates were obtained by crossing $\operatorname{Lrrc} 32^{t m 1.1 H f u j}$ mice with B6.129(Cg)-Foxp $3^{\text {tm4(YFP/icre)AyrJJ }}$, or $\operatorname{Tg}($ Pf4-icre)Q3Rsko, or Cd79a $a^{\text {tml(cre)Reth } / E h o b J ~ m i c e . ~ I l 22 ~} \mathrm{ral}^{-/-}\left(I l 22 \mathrm{r}^{-/-}\right)$mice were generated at the de Duve Institute [23]. Mice were maintained in an SPF animal facility at temperatures between 20 and $24{ }^{\circ} \mathrm{C}$, HR between 40 and $65 \%$, and day-night cycles of $12 \mathrm{~h}-12 \mathrm{~h}$. All animal studies were performed in accordance with national and institutional guidelines for animal care, under permit number 2017/UCL/MD/019 from the UCLouvain.

\section{Antibodies}

Clone 58A2 is a monoclonal mouse IgG2a antibody that binds mouse GARP:TGF- $\beta 1$ complexes and blocks active TGF- $\beta 1$ production by mouse cells in vitro [12]. Three to four biweekly intra-peritoneal (i.p.) injections of $250 \mu \mathrm{g}$ of $58 \mathrm{~A} 2 \mathrm{mAb}$ in combination with anti-PD1 were previously shown to exert anti-tumor effects in tumor-bearing mice [12]. Here, mice received two weekly i.p. injections of $400 \mu \mathrm{g}$ of 58A2. Clone 1D11 is a monoclonal mouse IgG1 antibody that neutralizes active TGF- $\beta$ [1, 2, and 3] (BioXcell).

\section{C. rodentium infections}

C. rodentium strain DBS100 (kindly provided by M. Chamaillard, Pasteur Institute, Lille, France) was cultured overnight in LB media at $37^{\circ} \mathrm{C}$. Concentration of bacteria in the cultures was assessed by measuring absorbance at $600 \mathrm{~nm}$ and converting into colony-forming units (CFU). Inoculation of $C$. rodentium $\left(10^{9} \mathrm{CFU}\right.$ in $200 \mu \mathrm{l}$ of PBS) was performed by oral gavage in 3-month-old mice. One day before infection and 6 days after, $400 \mu \mathrm{g}$ of anti-GARP:TGF- $\beta 1$ (clone 58A2) or anti-TGF- $\beta$ (clone 1D11) mAbs were injected i.p. . Mice were monitored daily for weight change, and sacrificed at the time point indicated in the figures, or if weight loss was $>20 \%$ by comparison today 0 . 


\section{Protein immunization}

To measure Ig responses, 3-month-old mice were injected i.p. with $100 \mu \mathrm{g}$ ovalbumin (OVA, Sigma) or $30 \mu \mathrm{g}$ Cholera Toxin B subtype (CTB, Enzo Life Science) emulsified in $100 \mu \mathrm{l}$ of Imject ${ }^{\circledR}$ Alum solution (Thermofisher) on day 0 , and $100 \mu \mathrm{g}$ OVA or $30 \mu \mathrm{g}$ CTB in PBS on day 9. Mice were bled on day 16 to measure OVA- or CTB- specific Igs in the serum. As indicated in the figures and their legends, some mice received $400 \mu \mathrm{g}$ of anti-GARP:TGF- $\beta 1$ i.p. on day -1 and 6 . To measure $\mathrm{T}_{\mathrm{H}}$ cell responses, 3-month-old mice were injected sub-cutaneously (s.c.) with $100 \mu \mathrm{g}$ OVA emulsified in $100 \mu \mathrm{l}$ of Complete Freund's Adjuvant (CFA, Thermofisher) on day 0 , then sacrificed to collect spleens on day 14.

\section{Tissue collection and Histology}

Colons were collected after sacrifice. Five mm-long terminal fragments were used for RT-qPCR analyses. For histological analyses, colons were placed in a Swiss roll shape, soaked in $10 \%$ formalin for $24 \mathrm{~h}$ then embedded into paraffin. $7 \mu \mathrm{m}$-sections were stained with hematoxylin and eosin. Histopathological scoring was adapted from previous reports [24, 25], by measuring lymphocyte infiltration, goblet cell- and crypt- damage, and colonic hyperplasia to attribute a colitis score ( 0 : no colitis; 1 : scattered inflammatory cells in the lamina propria, less than $25 \%$ of Goblet cell depletion, less than $25 \%$ of crypt thickness increase; 2 : increased numbers of inflammatory cells in the lamina propria, less than $50 \%$ of Goblet cell depletion, less than $50 \%$ of crypt thickness increase 3: confluence of inflammatory cells extending into the submucosa, less than $75 \%$ of Goblet cell depletion, less than $75 \%$ of crypt thickness increase; 4: transmural extension of the infiltrative inflammatory cell severe colitis, $100 \%$ of Goblet cell depletion, $100 \%$ of crypt thickness increase).

\section{Bacteria and CFU counts}

Fresh fecal samples were collected, weighed, and homogenized in cold sterile PBS ( $1 \mathrm{ml} / 100 \mathrm{mg}$ of feces). Bacterial DNA was extracted using QIAamp DNA Stool Mini Kit (Qiagen). Copy numbers of the C. rodentium Espb gene were measured by qPCR with the following primer set: $5^{\prime}-$ CGTCAGCAGCCTTTTCAGCTA -3', and 5'- ATGCCG CAGATGAGACAGTTG - $3^{\prime}$ and in $20 \mu$ reaction volumes containing Takyon Master Mix (Eurogentec) using StepOnePlus device (Thermofisher) with standard Thermal cycling parameters $\left(95^{\circ} \mathrm{C}\right.$ for $3^{\prime} ; 50$ cycles of $95^{\circ} \mathrm{C}$ for $10^{\prime \prime}$ and $60^{\circ} \mathrm{C}$ for $\left.60^{\prime \prime}\right)$.

Livers were collected, weighed and homogenized, and titrated in PBS. Series of liver homogenate dilutions were spread on LB semi-solid culture medium and incubated at 37 ${ }^{\circ} \mathrm{C}$ overnight. Bacterial colonies were counted to determine CFUs and normalized to the weight of the livers.

\section{Mixed lymphocyte cultures}

15 days after immunization with OVA in CFA, spleens were collected and $\mathrm{CD}^{+}{ }^{+} \mathrm{T}$ cells were sorted by MACS (Miltenyi Biotech) with anti-mouse $\mathrm{CD} 4^{+}$beads. $2 \times 10^{5} \mathrm{CD}^{+}$ cells were seeded with irradiated syngeneic adherent cells pulsed with OVA. Adherent cells were obtained by coating $1 \times 10^{6}$ splenocytes in a 96 -well flat-bottomed plate for $1.5 \mathrm{~h}$, then removing non-adherent cells by washing with PBS, and pulsed with OVA $(50 \mu \mathrm{g} / \mathrm{ml})$ for $2 \mathrm{~h}$, before irradiation (30 Gy from a ${ }^{137} \mathrm{Cs}$ source). After $96 \mathrm{~h}$ of mixed lymphocyte culture, supernatants were collected to measure cytokines.

\section{RNA extraction and RT-qPCR}

Colonic tissues were disrupted with the Tissue Lyser (Qiagen), total RNA was isolated using Nucleospin Mini Columns (Macherey Nagel), and reverse transcribed into cDNA (Thermofisher). qPCR was performed in a StepOnePlus device (Applied Biosystems) in $20 \mu \mathrm{l}$ reaction volumes containing Takyon Master Mix (Eurogentec), cDNA, and primers. Thermal cycling parameters were either fast conditions $\left(95^{\circ} \mathrm{C}\right.$ for $3^{\prime} ; 50$ cycles of $95^{\circ} \mathrm{C}$ for 3 ', and $60{ }^{\circ} \mathrm{C}$ for $30^{\prime \prime}$ ) or standard conditions $\left(95^{\circ} \mathrm{C}\right.$ for $3^{\prime}$; 50 cycles of $95^{\circ} \mathrm{C}$ for $10^{\prime \prime}$ and $60^{\circ} \mathrm{C}$ for $\left.60^{\prime \prime}\right)$ depending on the amplicon size. The $b$-actin gene (primers obtained from Eurogentec; forward strand: 5'-ATTGCCGACAGGATGCAG AA-3'; reverse strand: 5'-GTCATACTCCTGCTTGCT GA-3'; Taqman probe: 5'-TCAAGATCATTGCTCCTCCTG AGC-3') was used to normalize relative gene expression. Primers were obtained from Eurogentec or IDT. The target genes included $1117 a$ (forward: 5'-GCTCCAGAAGGC CCTCAG-3'; reverse: 5'-CTTTCCCTCCGCATTGACA-3'; Taqman probe: $5^{\prime}$-ACCTCAACCGTTCCACGTCACCCT G-3'), Ifng (forward: 5'-TCAAGTGGCATAGATGTGGAA GAA-3'; reverse: 5'-TGGCTCT GCAGGATTTTCATG-3'; Taqman probe: $5^{\prime}$-TCACCATCCTTTTGCCAGTTCCTC CAG-3'), RegIIIb (forward: 5'-CTACTGCCTTAGACC GTGCTTTC-3'; reverse: 5'-GAGTCTTCACATTTTGTC CCTTGTC-3'; Taqman probe: 5'-GTGAAGTTGCCCTAT GTCTGC-3'), RegIIIg (forward: 5'-GAGTGGAGCAAT GCTGATGTGATG-3'; reverse: 5'-GGGATCTTGCTTGTG GCTAGG -), Il6 (forward: 5'-CAGAGTCCTTCAGAGAGA TACAGAAA-3'; reverse: 5'-TCCAGCTTATCTGTTAGG AGAGCATT-3'), Il4 (forward: 5'-GAACGAGGTCACAGG AGAAGG-3'; reverse: 5'-GGACTCATTCATGGTGCA GCTTA-3'; Taqman probe: 5'-CCTCACAGCAACGAA GAACACCACAG-3') and Il22 (forward: 5'-GCTGCCCGT 
CAACACCC-3'; reverse: 5'-CTGATCCTTAGCACTGAC TCCTC-3'; Taqman probe: 5'- TGAGGTGTCCAACTTCCA GCAGCCA-3').

\section{ELISA}

Total serum $\operatorname{IgG}, \operatorname{IgM}$, and $\operatorname{IgA}$ were measured according to manufacturer instructions using IgG, IgM, and IgA ELISAs kits (Thermo Scientific). To measure $C$. rodentium- specific serum Igs, bacteria were lysed by sonication in PBS, C. rodentium proteins were enriched with bacterial protein extraction reagent (Thermo Scientific), then coated overnight at $4{ }^{\circ} \mathrm{C}(10 \mu \mathrm{g} / \mathrm{ml}, 100 \mu \mathrm{l})$ prior to incubation with various dilutions of mouse sera as indicated in the figures. Similarly, to measure OVA- and CTB- specific Igs, OVA $(15 \mu \mathrm{g} / \mathrm{ml}, 100 \mu \mathrm{l})$ or CTB $(4 \mu \mathrm{g} / \mathrm{ml}, 100 \mu \mathrm{l})$ were coated overnight at $4{ }^{\circ} \mathrm{C}$ on microtiter plates. $C$. rodentium-, OVAor CTB- specific IgGs, IgMs, and IgAs were measured using detection antibodies from the IgG, IgM, and IgA ELISA kits. Cytokines in culture supernatants were also measured by ELISA (murine IFN $\gamma$ ELISA, R\&D Systems; murine IL17a ELISA, with antibodies described in [26]). Absorbance readings were made at $450 \mathrm{~nm}$, using a 96-well plate spectrophotometer with GloMax Discover (Promega).

\section{Flow cytometry}

Splenocytes were stained with antibodies against surface markers (CD4, B220, CD41, and GARP) in the presence of a viability dye (eBioscience) and anti-CD16/32 to block Fc $\gamma$ Rs using a standard protocol. Tregs were stained with anti-Foxp3 using the eBioscience ${ }^{\mathrm{TM}}$ FOXP3/Transcription Factor Staining Kit (Invitrogen). Analyses were performed on a FACS LSR Fortessa flow cytometer (DIVA, BD Biosciences) and data were computed using the FlowJo software (Tree Star).

\section{Statistical analyses}

Statistical analysis was performed with Prism 5 (Graphpad Software) using non-parametric tests (Mann-Whitney), One-way ANOVA (Bonferroni multiple comparison posttests), and Log-rank Test for survival curves. $P$-value is shown if it is lower than 0.5 .

\section{Results}

\section{Anti-GARP:TGF- $\beta 1$ mAbs do not aggravate intestinal disease caused by $C$. rodentium infection}

Infection of wild-type C57BL/6 (WT) mice by oral gavage of $C$. rodentium is efficiently controlled by innate and adaptive immune responses, which prevent severe intestinal disease and weight loss $[16,17]$. To determine whether TGF- $\beta 1$ blockade could alter this control, we administered anti-GARP:TGF- $\beta 1$, anti-TGF- $\beta$, or PBS one day before and six days after the oral gavage (Fig. 1a). Whereas the anti-GARP:TGF- $\beta 1 \mathrm{mAb}$ (clone 58A2) blocks activation of latent TGF- $\beta 1$ at the surface of GARP expressing cells such as Tregs [12], anti-TGF- $\beta$ mAb (clone 1D11) neutralizes active TGF- $\beta 1, \beta 2$, and $\beta 3$, whichever their cellular source. No obvious symptom and no weight loss were observed, and all mice survived in all groups, indicating that TGF- $\beta$ signals are not required to prevent severe intestinal disease in WT mice (Fig. $1 \mathrm{~b}$ and supplementary Fig. 1a).

IL-22 signaling is crucial in the early phase of host defense against intestinal infection. In contrast to WT mice, $I l 22^{-/-}$and $I l 22 r^{-/-}$mice are highly susceptible to C. rodentium infection, which causes severe epithelial damage in the intestine, weight loss, systemic bacterial burden, and high mortality in these mice $[19,27]$. We thus tested whether TGF- $\beta 1$ blockade with anti-GARP:TGF- $\beta 1 \mathrm{mAbs}$ would increase the severity of disease in these mice. Mice receiving control PBS injections started to lose weight 8 days after infection and had lost $17 \pm 8 \%$ (mean \pm sem) of their initial weight by the end of the experiment on day 15 (Fig. 1c). Only 30\% of the mice survived until the end of the experiment (supplementary Fig. 1b). Injections of antiGARP:TGF- $\beta 1 \mathrm{mAbs}$ did not exacerbate weight loss, which was even slightly, although not significantly, less pronounced than in PBS-injected mice $(11 \% \pm 8 \%)$. In line with this, more than $65 \%$ of mice receiving anti-GARP:TGF- $\beta 1$ mAbs survived until the end of the experiment (supplementary Fig. 1b). Histological analyses of colons collected 9 days after gavage confirmed epithelial damage and inflammation, which were not more severe in mice that had received anti-GARP:TGF- $\beta 1$ mAbs (supplementary Fig. 1c). We used qPCR to measure $C$. rodentium numbers in the feces at multiple time points after oral gavage (Fig. 1d). After an initial drop on day $2, C$. rodentium numbers per gram of feces started to increase on day 3 , to reach a maximum of $10^{8}-10^{10}$ on day 9 . No significant difference was observed in mice receiving anti-GARP:TGF- $\beta 1 \mathrm{mAbs}$ (Fig. 1d). We also measured $C$. rodentium $\mathrm{CFU}$ in liver homogenates, to evaluate systemic bacterial burden on day 9 . No significant difference was observed in $I l 22 r^{-/-}$mice that had received anti-GARP:TGF- $\beta 1$ by comparison to PBS (Fig. 1e).

Taken together, these results indicate that antiGARP:TGF- $\beta 1 \mathrm{mAbs}$ do not reduce control of bacterial proliferation nor does it aggravate the severity of disease induced by $C$. rodentium infection in WT mice or in highly susceptible $I l 22 r^{-/-}$mice. 

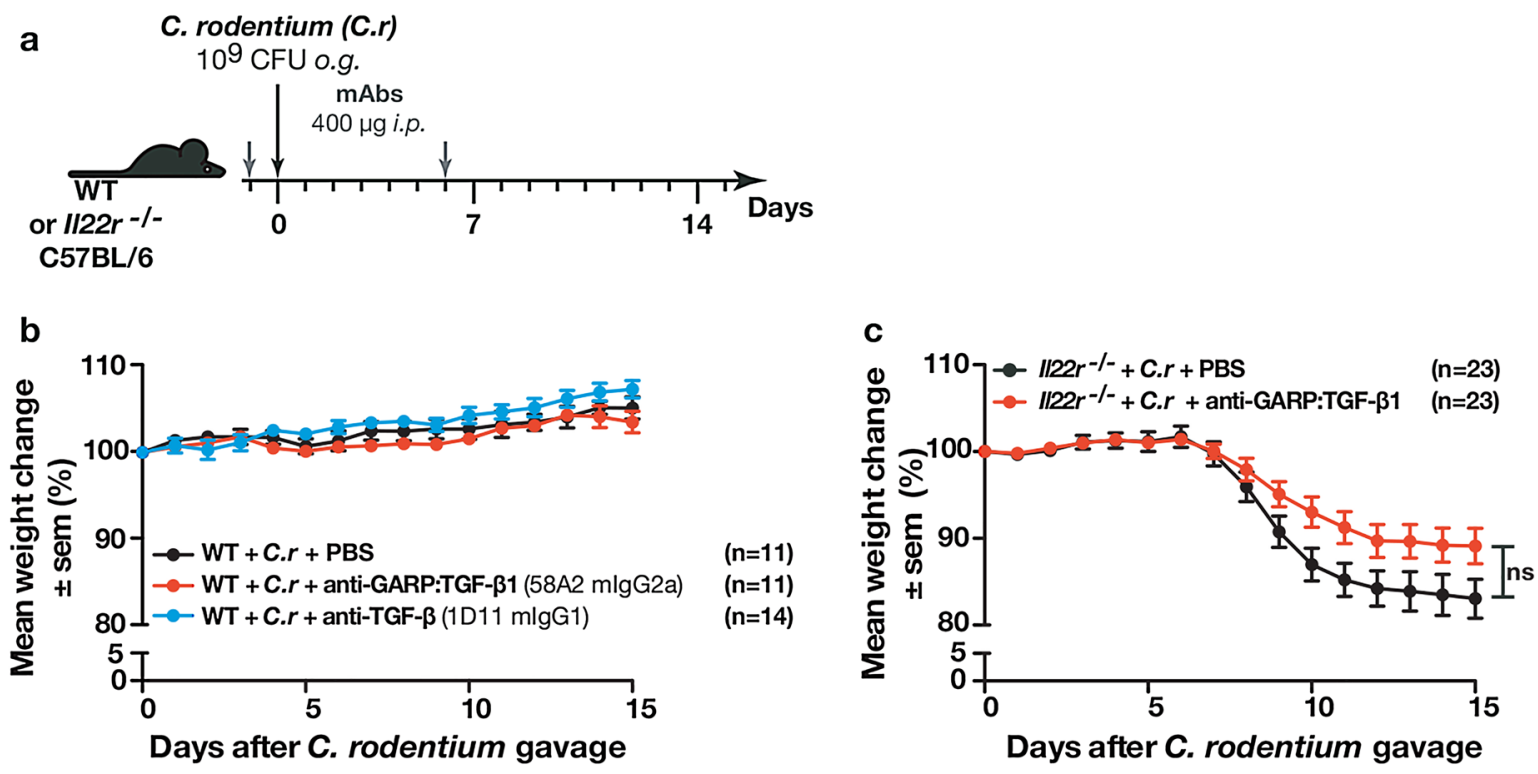

d

$(n=11)$

$(n=14)$

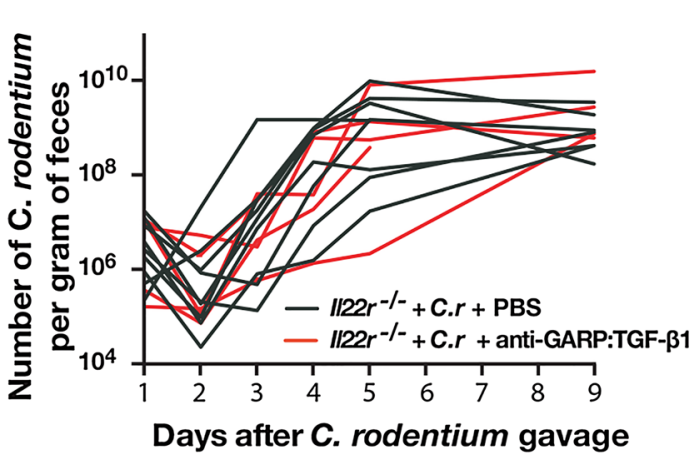

e

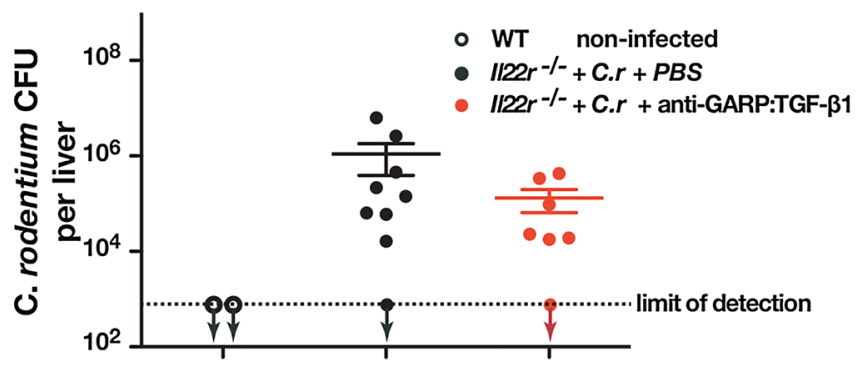

Fig. 1 Antibody-mediated blockade of TGF- $\beta 1$ produced from GARP:TGF- $\beta 1$ complexes does not aggravate intestinal disease induced by $C$. rodentium infection. a Schematic representation of the experimental design. Three-month-old C57BL/6 wild-type (WT B6) or $I l 22 r^{-/-}$mice received i.p. injections of PBS, anti-GARP:TGF- $\beta 1$ or anti-TGF- $\beta$ mAbs 1 day before, and 6 days after oral gavage with C. rodentium $(C . r)$. b-c Mice were monitored daily for weight loss. Data pooled from 2 to 3 independent experiments. Data points represent mean weight change per group \pm sem. $n=$ number of mice per

\section{Anti-GARP:TGF- $\beta 1$ mAbs do not modify innate and adaptive immune responses to intestinal $C$. rodentium infection}

Control and clearance of $C$. rodentium infection require both innate and adaptive immune responses $[16,28]$. We tested whether anti-GARP:TGF- $\beta 1 \mathrm{mAbs}$ could alter these responses in the intestines of highly susceptible $I l 22 r^{-/-}$mice. Mice received $C$. rodentium by oral gavage on day 0 , and i.p. injections of anti-GARP:TGF- $\beta 1$ or PBS on days -1 and +6 . Weights were measured daily (Fig. $2 a$ ), and sera and colons were collected 9 days after gavage.

group. Statistical analysis was performed by ANOVA with a Bonferroni post-test. d $C$. rodentium numbers were evaluated by quantification of espB gene copy number in the feces by qPCR. Each line represents values measured in one mouse. e $C$. rodentium $\mathrm{CFUs}$ in the livers collected 9 days after oral gavage. Each data point represents the value measured in one mouse. Statistical analysis was performed with a Mann-Whitney unpaired t-test. No statistically significant difference was observed between infected mice treated with PBS or antiGARP:TGF- $\beta 1(P>0,05)$

We first measured intestinal levels of mRNAs encoding molecules implicated in innate responses. High susceptibility to $C$. rodentium in absence of IL-22 signaling occurs mostly because IL-22 is required to induce expression of antimicrobial peptides RegIII $\beta$ and RegIII $\gamma$ in colonic epithelial cells [19]. Accordingly, we observed that RegIIIb and RegIIIg mRNAs were induced in the intestines of infected $I l 22 r^{-/-}$mice by comparison to noninfected mice, but to levels $\pm 10-100$ times lower than in infected WT mice (Fig. 2b and supplementary Fig. 2). Nevertheless, anti-GARP:TGF- $\beta 1 \mathrm{mAbs}$ did not reduce RegIIIb and RegIIIg expression in infected $I l 22 r^{-/-}$or WT mice (Fig. 2b, supplementary Fig. 2 and data not shown). 

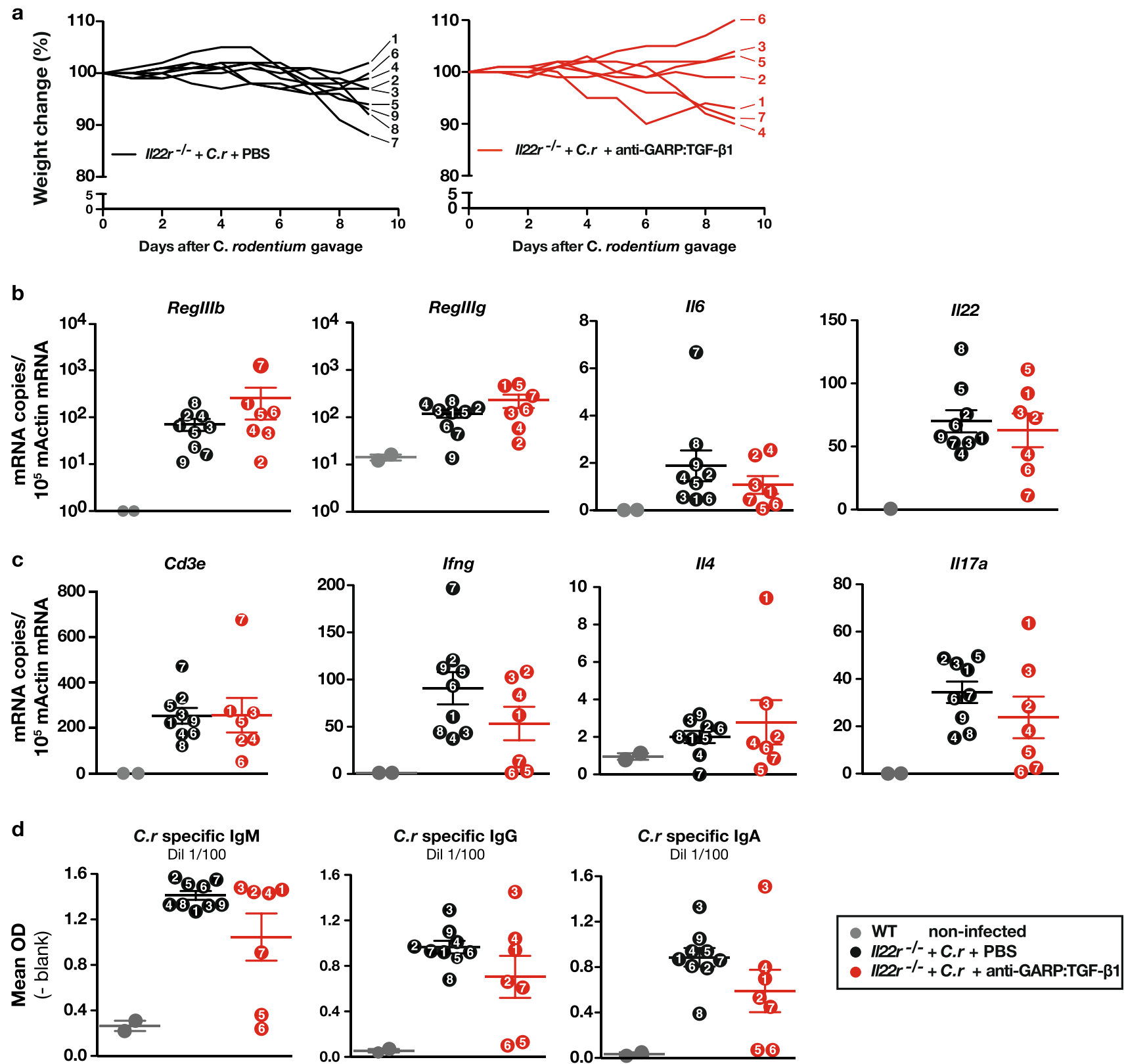

Fig. 2 Antibody-mediated blockade of TGF- $\beta 1$ produced from GARP:TGF- $\beta 1$ complexes do not impair innate or adaptive immune responses against intestinal $C$. rodentium infection. Three-month-old $I l 22 r^{-/-}$mice received i.p. injections of PBS or anti-GARP:TGF- $\beta 1$ mAbs 1 day before, and 6 days after oral gavage with $C$. rodentium. Mice were monitored daily for weight loss and sacrificed on day 9 , to collect colons and sera. a Weight change in individual mice. Each line represents one mouse, with individual mouse ID numbers indicated next to the corresponding line. b-c Expression of the indicated genes, normalized to $b$-actin expression, as measured by RT-qPCR in

colon samples. d C. rodentium-specific $\operatorname{IgM}, \operatorname{IgG}$, and $\operatorname{IgA}$, as measured in $1 / 100$ dilutions of serum samples by ELISA. Data points show mean value (technical duplicates) in each individual mouse (mouse ID number is indicated within each data point). Horizontal bars represent mean \pm sem per group. Data is representative of three independent experiments. Statistical analysis was performed with a Mann-Whitney unpaired t-test. No statistically significant difference was observed between infected mice treated with PBS or antiGARP:TGF- $\beta 1(P>0,05)$

Similar results were observed for expression of $I l 6$ and Il22 itself, taken here as representative of innate immune responses (Fig. 2b).

We next measured intestinal expression of mRNAs encoding $C D 3 \varepsilon$ and cytokines produced by helper $T\left(T_{H}\right)$

cells. As expected, expression of $C d 3 e$, Ifng, and $I l 17 a$ was clearly induced by comparison to non-infected mice, whereas that of $I l 4$ was not. Here again, anti-GARP:TGF- $\beta 1$ mAbs did not significantly reduce expression of any of these $\mathrm{T}$ cell marker or $\mathrm{T}_{\mathrm{H}}$ cell-derived cytokines by comparison 
to control PBS injections (Fig. 2c). Finally, we measured C. rodentium-specific $\operatorname{IgM}, \operatorname{IgG}$ and $\operatorname{Ig} \mathrm{A}$ in $1 / 100$ dilutions of sera by ELISA. Most mice had induced high levels of C. rodentium-specific $\operatorname{IgM}, \operatorname{IgG}$, and $\operatorname{Ig} \mathrm{A}$, whether or not they had received anti-GARP:TGF- $\beta 1 \mathrm{mAbs}$ (Fig. $2 \mathrm{~d}$ ). Interestingly, two mice that had received anti-GARP:TGF- $\beta 1$ (mice 5 and 6) did not develop strong $\operatorname{IgM}, \operatorname{IgG}$, and $\operatorname{Ig} \mathrm{A}$ responses against the bacteria. They correspond to mice that did not develop severe colitis and weight loss (Fig. 2a) and showed only very minor inductions of $\mathrm{T}_{\mathrm{H}} 1$ and $\mathrm{T}_{\mathrm{H}} 17$ cytokine genes in the colons (Fig. 2c). Thus, they appear to correspond to mice that did not develop significant infection and consequent immune responses upon oral gavage with C. rodentium.

Taken together, these results indicate that neither innate nor adaptive immune responses against $C$. rodentium in highly susceptible $I l 22 r^{-/-}$mice are altered by antiGARP:TGF- $\beta 1 \mathrm{mAbs}$. If anything, anti-GARP:TGF- $\beta 1$ $\mathrm{mAbs}$ tend to protect $I l 22 r^{-/-}$mice against severe intestinal disease and mortality induced by $C$. rodentium infection, although differences by comparison to PBS controls were not always statistically significant (Fig. 1c, supplementary Fig. 1b, and Fig. 2a).

\section{Anti-GARP:TGF- $\beta 1$ mAbs do not alter production of antigen-specific $\lg M$, IgG, or $\lg A$ following protein immunization}

Our group previously reported that blocking antiGARP:TGF- $\beta 1 \mathrm{mAbs}$ impaired switch to IgA production in human B cells stimulated in vitro [9]. We thus sought to determine whether TGF- $\beta 1$ production from GARP:TGF- $\beta 1$ complexes could regulate Ig production and isotype switching in non-infectious immunization models that induce strong Ig responses in mice. We primed WT B6 mice with ovalbumin (OVA) in alum and boosted them in PBS on day 9. Mice also received PBS or anti-GARP:TGF- $\beta 1$ injections 1 day before and 6 days after priming (Fig. 3a). Immunization induced abundant anti-OVA $\operatorname{IgM}, \operatorname{IgG}$, and $\operatorname{IgA}$, none of which were reduced by anti-GARP:TGF- $\beta 1 \mathrm{mAbs}$ (Fig. 3b-c).

\section{Genetic deletion of Garp in Tregs, B cells, or platelets does not modify production of antigen-specific IgM, IgG, or IgA following protein immunization}

To exclude cell-type-restricted effects of GARP:TGF- $\beta 1$ blockade, we performed protein immunizations in mice carrying a Treg-, B cell- or platelet-specific deletion of the Garp gene. Complete and specific Cre-mediated deletion of Garp in the expected cell type is observed in each of the three mouse strains, namely Foxp $3^{\mathrm{Cre}}$ x $\mathrm{Garp}^{\mathrm{A} / \mathrm{fl}}, \mathrm{Mbl}^{\mathrm{Cre}}$ x $G a r p^{f l f l}$, and $P f 4^{C r e}$ x $G a r p^{f l f l}$ mice (supplementary
Fig. 3a). All cell-type-specific knock-out (KO) mice have serum levels of various Ig isotypes that are similar to those found in the corresponding WT littermates (Supplementary Fig. 3b). Treg-specific Garp KOs and WT littermates were immunized with OVA in alum as above. Immunization induced similar levels of anti-OVA $\operatorname{IgM}, \operatorname{IgG}$, and $\operatorname{Ig} \mathrm{A}$ in WT and KOs (supplementary Fig. 4). We also used another antigen, cholera toxin B (CTB), to immunize Treg- and other cell type-specific Garp KOs and WT littermates (Fig. 4a). CTB in alum is also known to induce high levels of antigenspecific IgM, IgG, and IgA [29, 30]. We confirmed that the absence of GARP on Tregs did not modify levels of anti-CTB IgM, IgG, and IgA in serum (Fig. $4 \mathrm{~b}-\mathrm{c}$ ). $M b 1^{\mathrm{Cre}} \mathrm{X}$ $G a r p^{f / f l}$ and $P f 4^{C r e}$ x Garp ${ }^{f / f l}$ mice and their WT littermates were also immunized with CTB in alum and levels of serum anti-CTB IgM, IgG and IgA 16 days after priming were similar in B cell- and platelet- Garp KOs by comparison to their corresponding WT littermates (Fig. 4b-c). A trend towards slightly reduced anti-CTB IgM was observed in B cell-Garp KOs, but this difference was not statistically significant (Fig. 4c).

\section{Genetic deletion of Garp in Tregs, B cells, or platelets does not impair OVA-specific TH responses following OVA immunization}

We examined whether $\mathrm{T}_{\mathrm{H}}$ cell differentiation is altered in cell type-specific Garp KOs upon protein immunization. Garp KOs and their WT littermates were immunized with OVA in Complete Freund's Adjuvant (CFA). CFA is known to favor potent $T_{H}$ response and notably $T_{H} 17$ responses [31], which could be impaired if TGF- $\beta$ activation is reduced. Fourteen days after immunization, splenocytes were collected and re-stimulated in vitro with APCs pulsed with OVA to measure IL-4, IFN $\gamma$, and IL-17a production in the supernatants (Fig. 5a). Splenocytes from all mice immunized with OVA produced abundant IFN $\gamma$ and IL-17a, but no IL-4. Importantly, no difference was observed between cell-type-specific Garp KOs and their corresponding WT littermates (Fig. 5b-d).

Altogether, our results indicate that TGF- $\beta 1$ production from GARP:TGF- $\beta 1$ complexes on Tregs, B cells, or platelets does not significantly impact antibody production and $\mathrm{T}_{\mathrm{H}}$ cell differentiation following immunization with protein in vivo.

\section{Discussion}

Our observations suggest that anti-GARP:TGF- $\beta 1 \mathrm{mAbs}$ do not alter innate or adaptive immune responses against C. rodentium infection in mice. This may be considered reassuring with regards to the risk of increased susceptibility to intestinal infection and inflammation that could be 
a

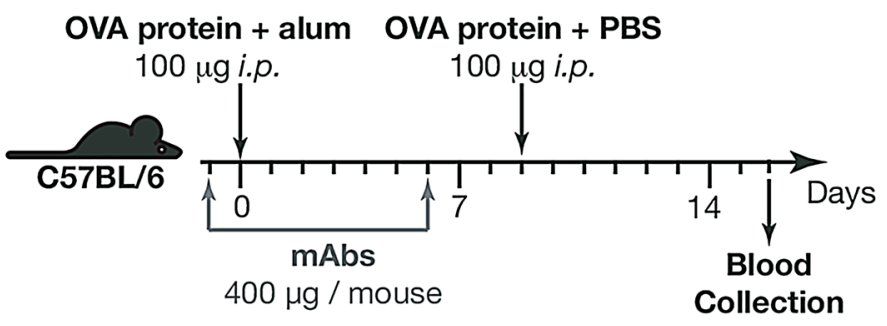

\section{b}

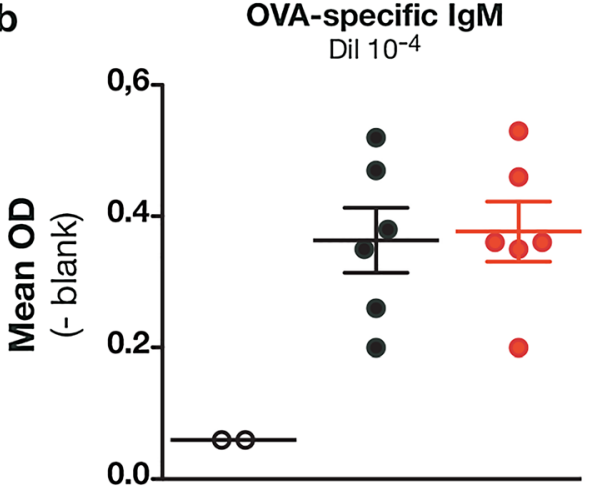

C

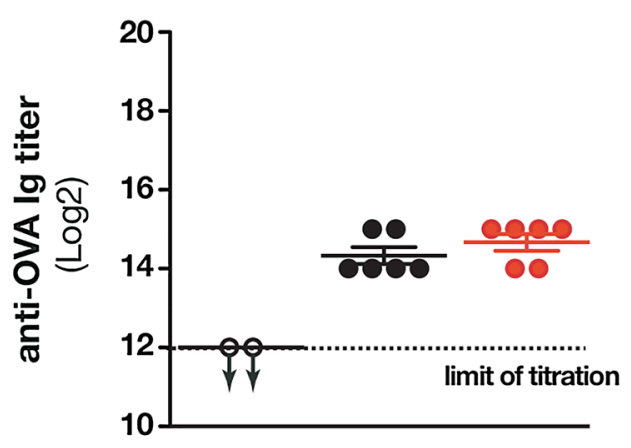

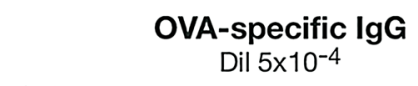

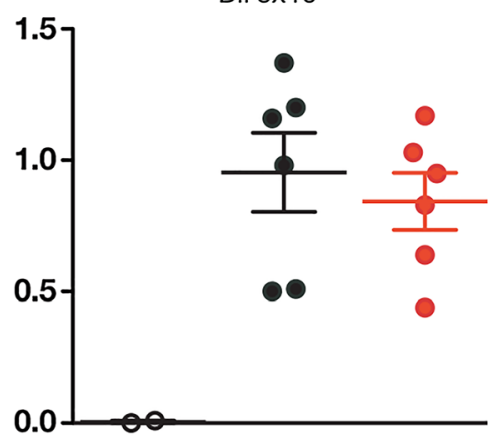

OVA-specific IgG

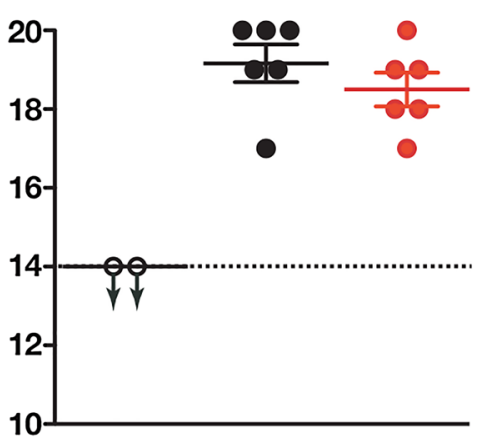

O No immunisation

- OVA + alum

- OVA + alum + anti-GARP:TGF- $\beta 1$

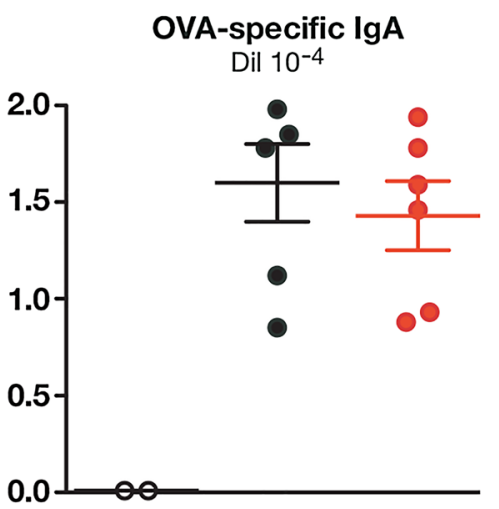

OVA-specific IgA

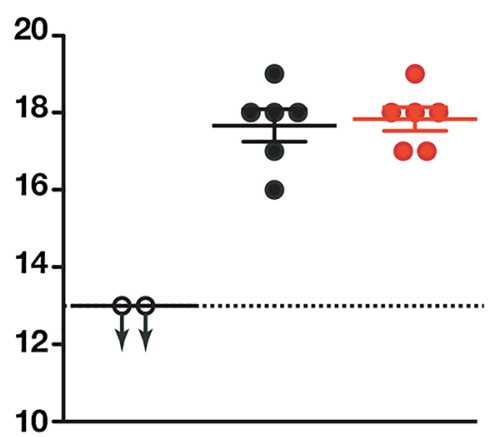

Fig. 3 Antibody-mediated blockade of TGF- $\beta 1$ produced from GARP:TGF- $\beta 1$ complexes does not modify the amplitude of OVAspecific $\mathrm{Ab}$ responses upon immunization with OVA and alum. a Schematic representation of the experimental design. Three-monthold C57BL/6 mice were treated with mAbs 1 day before and 6 after i.p. OVA protein immunization with alum. After 9 days, OVA protein in PBS was injected i.p. as boost. Blood was collected on day 16 to

associated with the use of anti-GARP:TGF- $\beta 1 \mathrm{mAbs}$ for cancer immunotherapy. It also suggests that TGF- $\beta 1$ derived from GARP-expressing cells does not play important role in regulating immune responses to bacterial infections at the level of mucosal barriers.

Zhang et al. reported that $\mathrm{C}$. rodentium infection downregulates expression of TGF- $\beta$ receptor chains I and II and of Smad2 in mouse colons [32]. They suggested that these downregulations promote inflammation and contribute to disease pathogenesis. Their observations could explain the absence of effect of anti-GARP:TGF- $\beta 1 \mathrm{mAbs}$ observed here in mice infected with $C$ rodentium if TGF- $\beta 1$ signaling measure OVA-specific Igs in sera by ELISA. b-c Data points represent values in individual mice. Horizontal lines indicate mean \pm sem $(n=6$ mice per group). Statistical analysis was performed with a Mann-Whitney unpaired $t$-test. No statistically significant difference was observed between OVA-immunized mice treated with PBS or anti-GARP:TGF- $\beta 1(P>0,05)$. Results shown are representative of two independent experiments

was already inhibited by the pathogen and did not participate in the immune responses.

Host defense against $C$. rodentium also involves adaptive $\mathrm{T}_{\mathrm{H}} 17$ responses [28]. $\mathrm{T}_{\mathrm{H}} 17$ differentiation depends on IL-23 and TGF- $\beta 1$. IL-23-deficient $\left(p 19^{-/-}\right)$mice treated with antiTGF- $\beta 1 \mathrm{mAbs}$ developed severe colitis associated with a strong decrease of $\mathrm{T}_{\mathrm{H}} 17$ cells [33]. Backert et al. confirmed this observation with a TGF- $\beta$ inhibitor in STAT3-deficient mice highly susceptible to $C$. rodentium infection [34]. Interestingly, we observed that anti-GARP:TGF- $\beta 1 \mathrm{mAbs}$ did not alter $I l 17 a$ mRNA expression in the colons of $C$. rodentium-infected $I l 22 r^{-/-}$mice, suggesting that active TGF- $\beta 1$ 


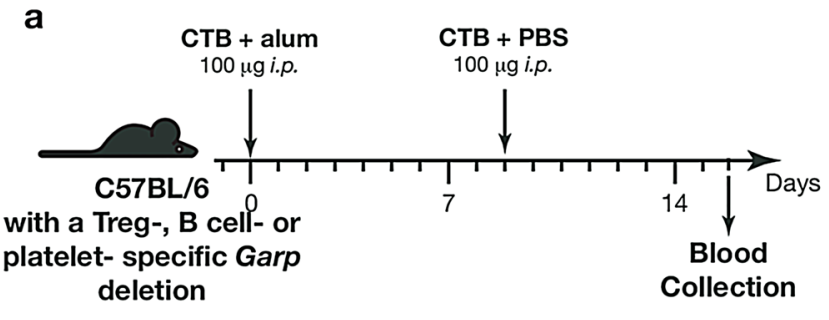

b
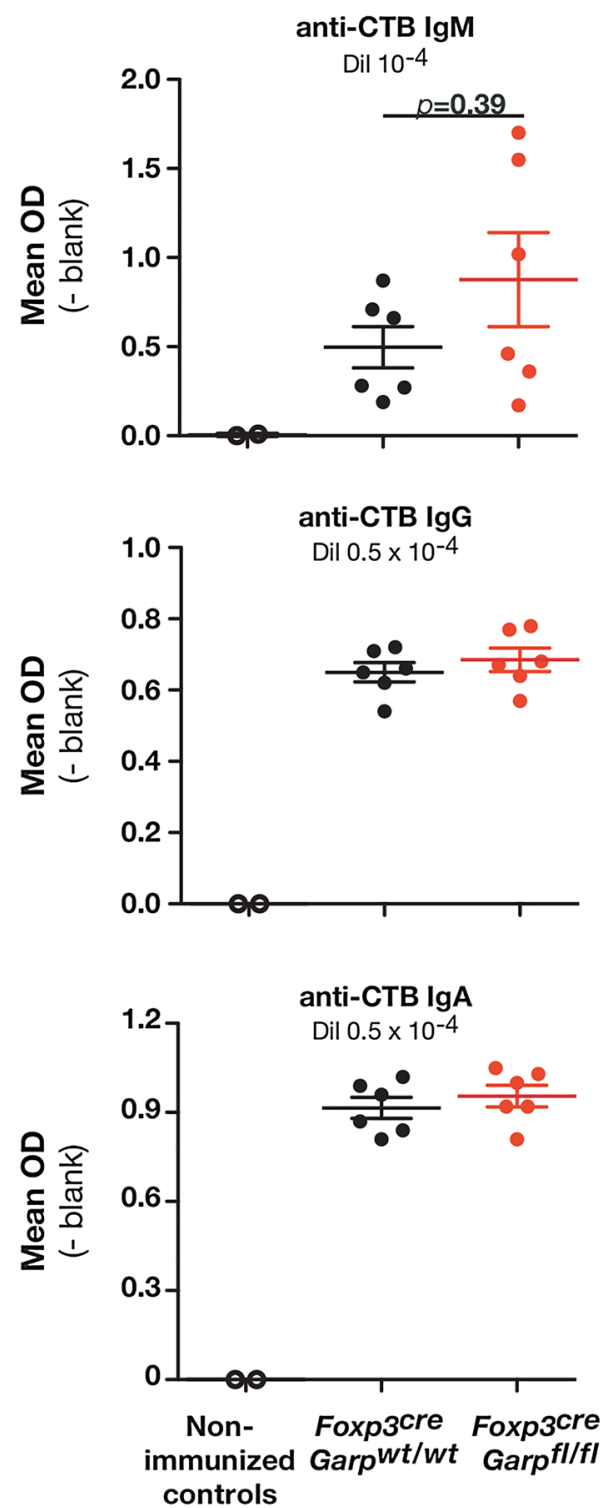

c

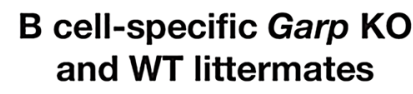

anti-CTB IgM

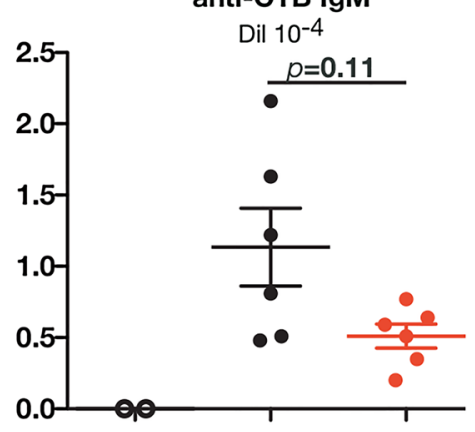

anti-CTB $\lg G$
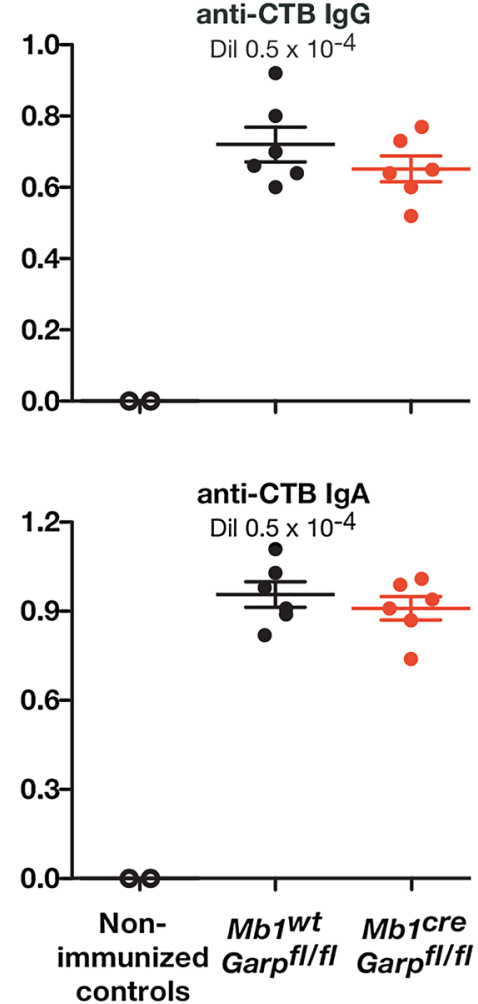

\section{Platelet-specific Garp KO} and WT littermates

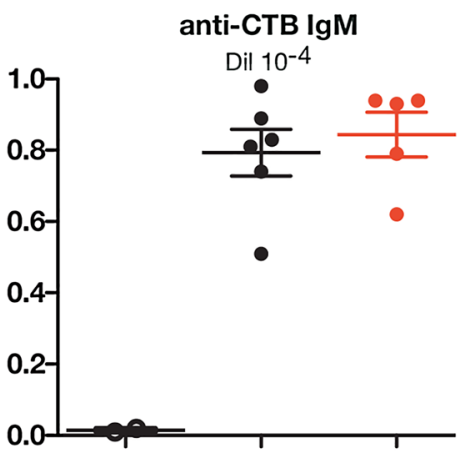

anti-CTB IgG

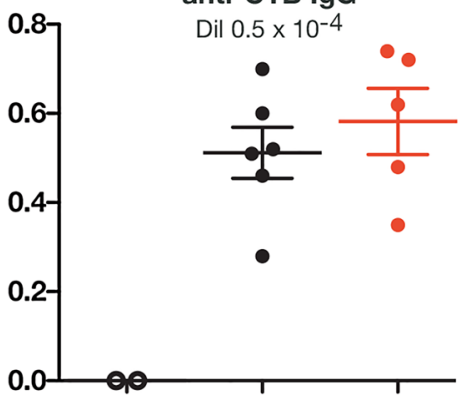

anti-CTB IgA

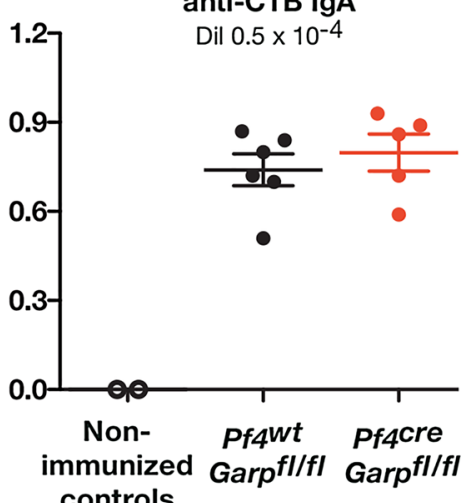

Fig. 4 Genetic deletion of Garp in Tregs, B cells, or platelets does not modify CTB-specific Ig responses upon CTB immunization. a Schematic representation of the experimental design. Genetically modified C57BL/6 mice (3-month-old) were injected i.p. with CTB in alum on day 0 , and CTB in PBS on day 9. Blood was collected on day 16 to measure CTB specific-Igs in serum by ELISA. b-d Data points represent values in individual mice. Horizontal lines show mean $\pm \operatorname{sem}(n=5-6$ mice per group). Statistical analysis was performed with a Mann-Whitney unpaired $t$-test (to compare groups of CTB-immunized mice treated with PBS or anti-GARP:TGF- $\beta 1$ ) and $p$-value is shown if it is lower than 0.5 
a

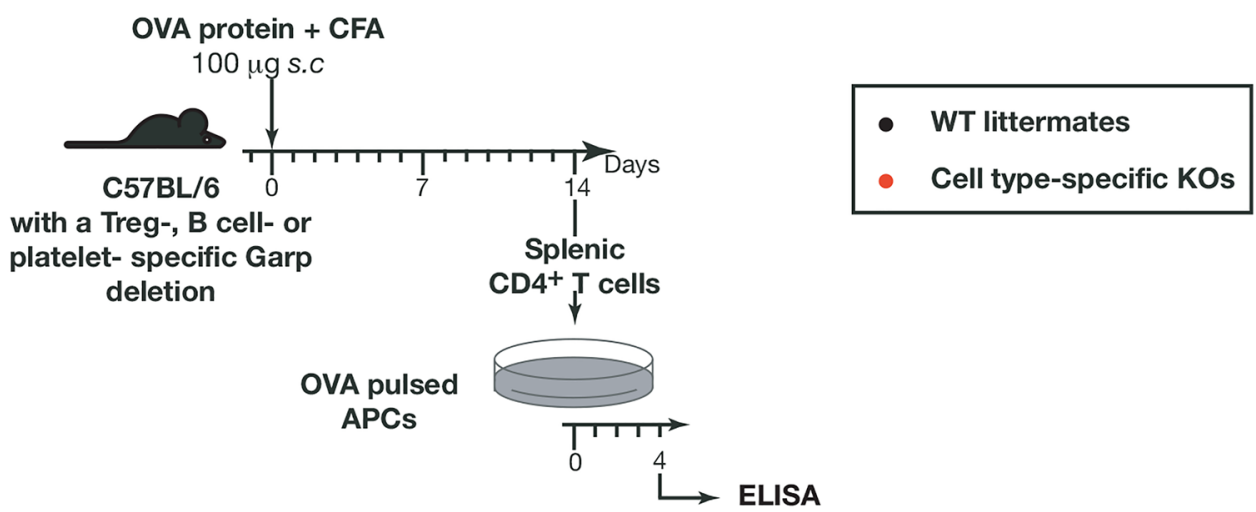

b

Treg-specific Garp KO and WT littermates
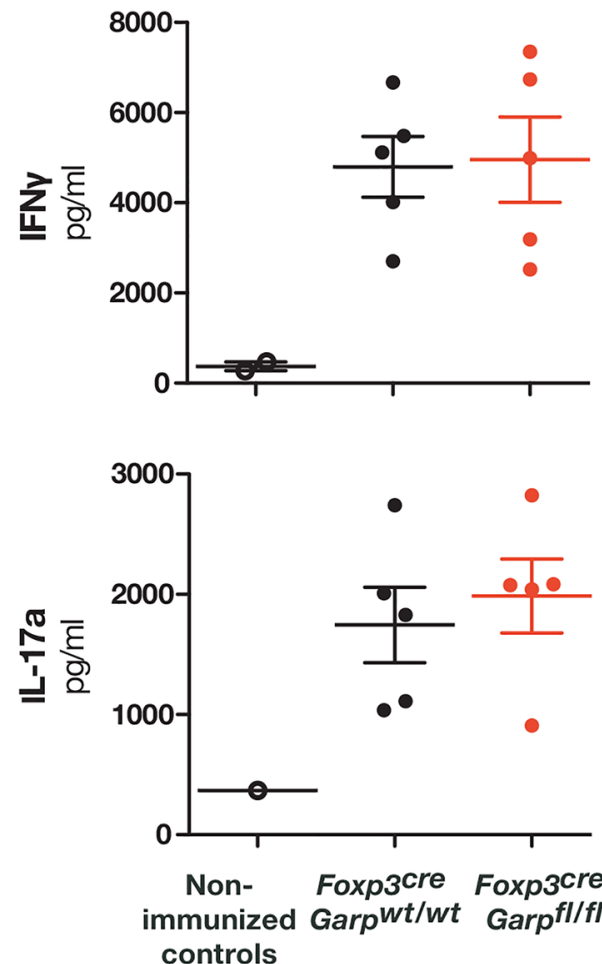
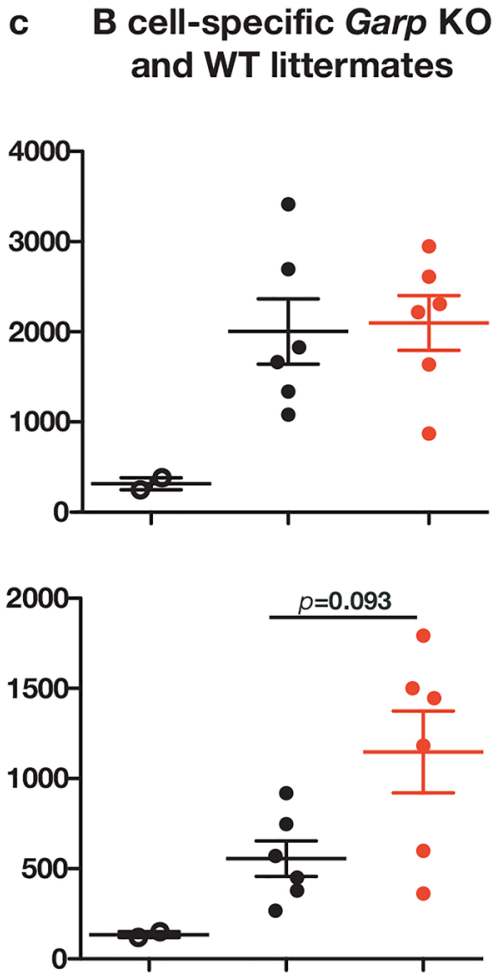

Nonimmunized controls

\section{d Platelet-specific Garp KO and WT littermates}
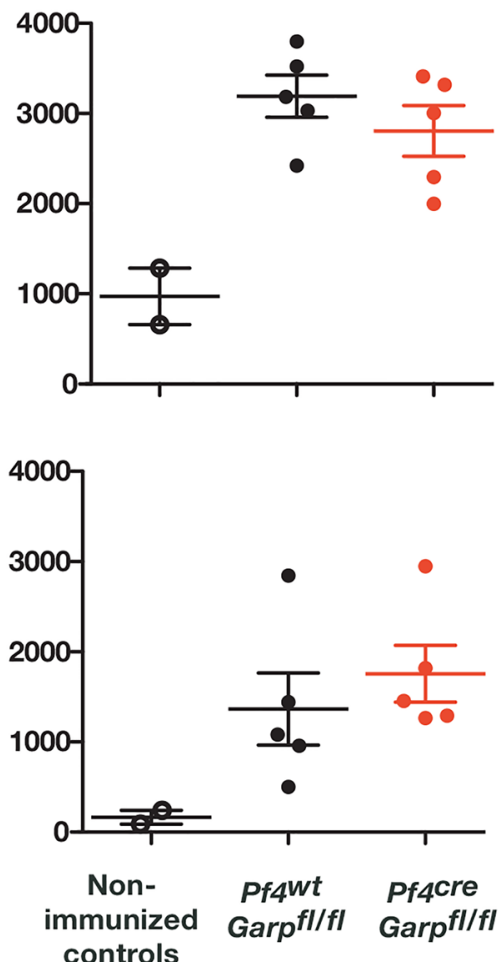

Fig. 5 Genetic deletion of GARP in Tregs, B cells, or platelets does not modify OVA-specific $T_{H}$ responses upon immunization with OVA and CFA. a Schematic representation of the experimental design. Genetically modified C57BL/6 mice (3-month-old) were injected s.c. with OVA protein and CFA on day 0 . B-c 14 days after OVACFA immunization, spleen cells were collected and $\mathrm{CD}^{+}$cells were purified by MACS before incubation with adherent stimulating cells

released from GARP:TGF- $\beta 1$ complex does not contribute to $\mathrm{T}_{\mathrm{H}} 17$ differentiation in this setting.

B cells and production of $C$. rodentium-specific IgGs are also required for complete clearance of $C$. rodentium [22]. Following C. rodentium infection, $I l 22 \mathrm{r}^{-/-}$mice produced specific IgG, IgM, and IgA, and this production was not pulsed with OVA. After 4 days of co-culture, IFN $\gamma$ and IL-17a production were measured by ELISA. Data in all panels are means \pm sem ( $n=5-6$ mice per group) and are representative of two to three independent experiments Statistical analysis was performed with MannWhitney unpaired t-test (to compare the groups of CTB-immunized mice treated with PBS or anti-GARP:TGF- $\beta 1$ ) and p-value is shown if it is lower than 0.5

altered by administration of anti-GARP:TGF- $\beta 1 \mathrm{mAbs}$. This observation was unexpected. Indeed, we previously showed that blocking anti-GARP:TGF- $\beta 1 \mathrm{mAbs}$ hampered isotype switching towards IgA by human B cells in vitro [9], suggesting that $\mathrm{B}$ cells could produce themselves the active TGF- $\beta 1$ required for IgA secretion [15, 35]. However, our 
data here in mice showed that anti-GARP:TGF- $\beta 1 \mathrm{mAbs}$ did not impede the anti-OVA IgA response in vivo. Moreover, anti-CTB IgA response was not impeded in any of the cell type-specific Garp KOs used, including B cell-specific Garp KO. Altogether, these results suggest that the active TGF- $\beta 1$ required for IgA switching does not emanate from GARPexpressing cells, including B cells. This could be true when IgA switching occurs in vivo, upon immunization of mice with protein antigens. In our previous report using purified human B cells in vitro, IgA switching was observed after BCR stimulation with anti-IgM in the presence of $\mathrm{CpG}$, antiCD40L, and IL-21, but in the absence of any other cell types. In such experimental conditions in vitro, GARP-expressing human B cells may become a unique, predominant source of active TGF- $\beta 1$ allowing IgA switching, even though they may not significantly contribute to switching in vivo.

Anti-GARP:TGF- $\beta 1 \mathrm{mAbs}$ were shown to inhibit immunosuppression by human and mouse Tregs in vivo $[11,12]$. Here, we observe no obvious impact of these $\mathrm{mAbs}$ in a model of bacterial intestinal infection in mice. We thus suggest that anti-GARP:TGF- $\beta 1 \mathrm{mAbs}$ could be used to inhibit immunosuppression by Tregs in patients with cancer, without major risks of impairing immune responses to bacterial infection at mucosal barriers.

Supplementary Information The online version contains supplementary material available at https://doi.org/10.1007/s00262-021-03119-8.

Acknowledgments We thank E. Hemelrike for editorial assistance.

Author contributions Sophie Lucas conceived the study. Mélanie Gaignage, Xuhao Zhang, Julie Stockis, Olivier Dedobbeleer, Camille Michiels, Perrine Cochez, Laure Dumoutier and Sophie Lucas analyzed the data. Sophie Lucas, Pierre G. Coulie and Mélanie Gaignage wrote the manuscript. Mélanie Gaignage, Xuhao Zhang, Julie Stockis, and Camille Michiels performed experiments.

Funding This work was supported by grants from the Fondation contre le Cancer (Grant F/2016/837), from the European Research Council (ERC) under the European Union's Horizon 2020 research and innovation programme (Grant TARG-SUP 682818), from the Actions de Recherche Concertées (Grant 14/19-056), from the Fonds National de la Recherche Scientifique (PDR Number T.0089.16) and from Région Wallonne (program WALinnov, project IMMUCAN, convention number 1610119). Xuhao Zhang was supported by a grant from the China Scholarship Council. This work was supported by grants from Walloon Excellence in Life Sciences and Biotechnology (WELBIO), Wavre, Belgium (CR-2019A-02.).

\section{Declarations}

Conflict of interest Patents pertaining to blocking antibodies against human GARP:TGF-b1 have been filed under the Patent Cooperation Treaty (International application Number PCT/IB2019/053753), with Sophie Lucas, Pierre G. Coulie, and Laure Dumoutier as inventors and UCLouvain as applicant. The anti-mouse GARP:TGF-b1 antibody (clone 58A2) used herein is a surrogate for these antibodies. All other authors declare no competing interests.
Ethics approval All mice were bred at the SPF animal facility of the UCLouvain. C. rodentium infection and immunization studies were performed in accordance with national and institutional guidelines for animal care, under permit number 2017/UCL/MD/019 from the UCLouvain.

Open Access This article is licensed under a Creative Commons Attribution 4.0 International License, which permits use, sharing, adaptation, distribution and reproduction in any medium or format, as long as you give appropriate credit to the original author(s) and the source, provide a link to the Creative Commons licence, and indicate if changes were made. The images or other third party material in this article are included in the article's Creative Commons licence, unless indicated otherwise in a credit line to the material. If material is not included in the article's Creative Commons licence and your intended use is not permitted by statutory regulation or exceeds the permitted use, you will need to obtain permission directly from the copyright holder. To view a copy of this licence, visit http://creativecommons.org/licenses/by/4.0/.

\section{References}

1. Shull MM, Ormsby I, Kier AB et al (1992) Targeted disruption of the mouse transforming growth factor-beta 1 gene results in multifocal inflammatory disease. Nature 359:693-699. https:// doi.org/10.1038/359693a0

2. Kulkarni AB, Huh CG, Becker D et al (1993) Transforming growth factor beta 1 null mutation in mice causes excessive inflammatory response and early death. Proc Natl Acad Sci U S A 90:770-774. https://doi.org/10.1073/pnas.90.2.770

3. Shi M, Zhu J, Wang R, Chen X, Mi L, Walz T, Springer TA (2011) Latent TGF-beta structure and activation. Nature 474:343-349. https://doi.org/10.1038/nature10152

4. Lienart S, Merceron R, Vanderaa C et al (2018) Structural basis of latent TGF-beta1 presentation and activation by GARP on human regulatory T cells. Science 362:952-956. https://doi.org/ 10.1126/science.aau2909

5. Munger JS, Huang X, Kawakatsu H et al (1999) The integrin alpha $\mathrm{v}$ beta 6 binds and activates latent TGF beta 1: a mechanism for regulating pulmonary inflammation and fibrosis. Cell 96:319-328. https://doi.org/10.1016/s0092-8674(00)80545-0

6. Travis MA, Reizis B, Melton AC et al (2007) Loss of integrin alpha(v)beta8 on dendritic cells causes autoimmunity and colitis in mice. Nature 449:361-365. https://doi.org/10.1038/natur e06110

7. Tran DQ, Andersson J, Wang R, Ramsey H, Unutmaz D, Shevach EM (2009) GARP (LRRC32) is essential for the surface expression of latent TGF-beta on platelets and activated FOXP3+ regulatory T cells. Proc Natl Acad Sci U S A 106:13445-13450. https://doi.org/10.1073/pnas.0901944106

8. Stockis J, Colau D, Coulie PG, Lucas S (2009) Membrane protein GARP is a receptor for latent TGF-beta on the surface of activated human Treg. Eur J Immunol 39:3315-3322. https:// doi.org/10.1002/eji.200939684

9. Dedobbeleer O, Stockis J, van der Woning B, Coulie PG, Lucas S (2017) Cutting edge: active TGF-beta1 released from GARP/ TGF-beta1 complexes on the surface of stimulated Human B Lymphocytes Increases class-switch recombination and production of IgA. J Immunol 199:391-396. https://doi.org/10.4049/ jimmunol.1601882

10. Stockis J, Lienart S, Colau D, Collignon A, Nishimura SL, Sheppard D, Coulie PG, Lucas S (2017) Blocking immunosuppression by human Tregs in vivo with antibodies targeting 
integrin alphaVbeta8. Proc Natl Acad Sci U S A 114:E10161E10168. https://doi.org/10.1073/pnas.1710680114

11. Cuende J, Lienart S, Dedobbeleer O et al. (2015) Monoclonal antibodies against GARP/TGF-beta1 complexes inhibit the immunosuppressive activity of human regulatory $\mathrm{T}$ cells in vivo. Sci Transl Med 7:284ra56. https://doi.org/10.1126/scitr anslmed.aaa1983

12. de Streel G, Bertrand C, Chalon N et al (2020) Selective inhibition of TGF-beta1 produced by GARP-expressing Tregs overcomes resistance to PD-1/PD-L1 blockade in cancer. Nat Commun 11:4545. https://doi.org/10.1038/s41467-020-17811-3

13. Li MO, Wan YY, Flavell RA (2007) T cell-produced transforming growth factor-beta 1 controls $\mathrm{T}$ cell tolerance and regulates Th1- and Th17-cell differentiation. Immunity 26:579-591. https://doi.org/10.1016/j.immuni.2007.03.014

14. Edwards JP, Fujii H, Zhou AX, Creemers J, Unutmaz D, Shevach EM (2013) Regulation of the expression of GARP/latent TGF-beta1 complexes on mouse $\mathrm{T}$ cells and their role in regulatory T cell and Th17 differentiation. J Immunol 190:5506-5515. https://doi.org/10.4049/jimmunol.1300199

15. Cazac BB, Roes J (2000) TGF-beta receptor controls B cell responsiveness and induction of IgA in vivo. Immunity 13:443451. https://doi.org/10.1016/s1074-7613(00)00044-3

16. Silberger DJ, Zindl CL, Weaver CT (2017) Citrobacter rodentium: a model enteropathogen for understanding the interplay of innate and adaptive components of type 3 immunity. Mucosal Immunol 10:1108-1117. https://doi.org/10.1038/mi.2017.47

17. Mundy R, MacDonald TT, Dougan G, Frankel G, Wiles S (2005) Citrobacter rodentium of mice and man. Cell Microbiol 7:16971706. https://doi.org/10.1111/j.1462-5822.2005.00625.x

18. Basu R, O'Quinn DB, Silberger DJ, Schoeb TR, Fouser L, Ouyang W, Hatton RD, Weaver CT (2012) Th22 cells are an important source of IL-22 for host protection against enteropathogenic bacteria. Immunity 37:1061-1075. https://doi.org/10.1016/j.immuni. 2012.08.024

19. Zheng Y, Valdez PA, Danilenko DM et al (2008) Interleukin-22 mediates early host defense against attaching and effacing bacterial pathogens. Nat Med 14:282-289. https://doi.org/10.1038/ nm1720

20. Satoh-Takayama N, Vosshenrich CA, Lesjean-Pottier S et al (2008) Microbial flora drives interleukin 22 production in intestinal NKp46+ cells that provide innate mucosal immune defense. Immunity 29:958-970. https://doi.org/10.1016/j.immuni.2008.11. 001

21. Bry L, Brenner MB (2004) Critical role of T cell-dependent serum antibody, but not the gut-associated lymphoid tissue, for surviving acute mucosal infection with Citrobacter rodentium, an attaching and effacing pathogen. J Immunol 172:433-441. https://doi.org/ 10.4049/jimmunol.172.1.433

22. Maaser C, Housley MP, Iimura M et al (2004) Clearance of Citrobacter rodentium requires $\mathrm{B}$ cells but not secretory immunoglobulin A (IgA) or IgM antibodies. Infect Immun 72:3315-3324. https://doi.org/10.1128/IAI.72.6.3315-3324.2004

23. Van Belle AB, Cochez PM, de Heusch M et al (2019) IL-24 contributes to skin inflammation in Para-Phenylenediamine-induced contact hypersensitivity. Sci Rep 9:1852. https://doi.org/10.1038/ s41598-018-38156-4
24. Cevallos SA, Lee JY, Tiffany CR, Byndloss AJ, Johnston L, Byndloss MX, Baumler AJ (2019) Increased Epithelial Oxygenation Links Colitis to an Expansion of Tumorigenic Bacteria. mBio. 10. https://doi.org/10.1128/mBio.02244-19

25. Chen CC, Louie S, McCormick B, Walker WA, Shi HN (2005) Concurrent infection with an intestinal helminth parasite impairs host resistance to enteric Citrobacter rodentium and enhances Citrobacter-induced colitis in mice. Infect Immun 73:5468-5481. https://doi.org/10.1128/IAI.73.9.5468-5481.2005

26. Uyttenhove C, Van Snick J (2006) Development of an anti-IL-17A auto-vaccine that prevents experimental auto-immune encephalomyelitis. Eur J Immunol 36:2868-2874. https://doi.org/10.1002/ eji.200636662

27. Michiels C, Puigdevall L, Cochez P, Achouri Y, Cheou P, Hendrickx E, Dauguet N, Blanchetot C, Dumoutier L (2021) A targetable, noncanonical signal transducer and activator of transcription 3 activation induced by the Y-Less region of IL-22 receptor orchestrates imiquimod-induced psoriasis-like dermatitis in mice. J Invest Dermatol. https://doi.org/10.1016/j.jid.2021.04.016

28. Collins JW, Keeney KM, Crepin VF, Rathinam VA, Fitzgerald KA, Finlay BB, Frankel G (2014) Citrobacter rodentium: infection, inflammation and the microbiota. Nat Rev Microbiol 12:612623. https://doi.org/10.1038/nrmicro3315

29. Marinaro M, Staats HF, Hiroi T et al (1995) Mucosal adjuvant effect of cholera toxin in mice results from induction of $\mathrm{T}$ helper 2 (Th2) cells and IL-4. J Immunol 155:4621-4629

30. Lycke N (1997) The mechanism of cholera toxin adjuvanticity. Res Immunol 148:504-520. https://doi.org/10.1016/s09232494(98)80144-2

31. Brunner R, Jensen-Jarolim E, Pali-Scholl I (2010) The ABC of clinical and experimental adjuvants-a brief overview. Immunol Lett 128:29-35. https://doi.org/10.1016/j.imlet.2009.10.005

32. Zhang YG, Singhal M, Lin Z et al (2018) Infection with enteric pathogens Salmonella typhimurium and Citrobacter rodentium modulate TGF-beta/Smad signaling pathways in the intestine. Gut Microbes 9:326-337. https://doi.org/10.1080/19490976.2018. 1429878

33. Mangan PR, Harrington LE, O'Quinn DB et al (2006) Transforming growth factor-beta induces development of the $\mathrm{T}(\mathrm{H}) 17$ lineage. Nature 441:231-234. https://doi.org/10.1038/nature04754

34. Backert I, Koralov SB, Wirtz S et al (2014) STAT3 activation in Th17 and Th22 cells controls IL-22-mediated epithelial host defense during infectious colitis. J Immunol 193:3779-3791. https://doi.org/10.4049/jimmunol.1303076

35. Klein J, Ju W, Heyer J et al (2006) B cell-specific deficiency for Smad2 in vivo leads to defects in TGF-beta-directed IgA switching and changes in B cell fate. J Immunol 176:2389-2396. https:// doi.org/10.4049/jimmunol.176.4.2389

Publisher's Note Springer Nature remains neutral with regard to jurisdictional claims in published maps and institutional affiliations. 